\title{
STUDI KUALITATIF PENGALAMAN, PERSEPSI, DAN KESIAPAN ANAK DALAM MENGHADAPI MENARCHE DINI
}

\author{
${ }^{1}$ Ni Made Diaris, ${ }^{2}$ Indah Pramita \\ ${ }^{12}$ Fakultas Ilmu Kesehatan Sains dan Teknologi Universitas Dhyana Pura, Bali, \\ Email: madediaris@undhirabali.ac.id
}

\begin{abstract}
ABSTRAK
Penelitian sebelumnya mengggambarkan usia menarche semakin dini. Anak anak yang mengalami menarche dini cendrung belum siap dan cemas dalam menghadapi periode menstruasi. Tujuan penelitian ini adalah untuk mengetahui gambaran pengalaman, persepsi, dan kesiapan anak dalam menghadapi menarche dini Metode penelitian yang digunakan adalah metode kualitatif dengan wawancara mendalam yang dilakukan pada 20 anak yang berusia 10-12 tahun kemudian dianalisis secara thematic. Hasil: Sebagian besar anak memiliki pegetahuan yang cukup terkait menstruasi, namun ada beberapa anak yang mempunyai pengetahuan yang kurang karena belum pernah mendapat informasi yang benar terkait menstruasi terutama dari orang tua. Bagi anak yang sudah cukup pengetahuan dan informasinya terkait menstruasi cendrung menceritakan pengalaman yang positif terkait menarche dan menstruasi. Namun, untuk pengalaman seharihari di lingkungan temannya mereka cendrung merasa menstruasi itu hal yang membuat mereka malu terutama yang menstruasi lebih awal dari temannya. Dan dari hasil wawancara didapatkan bahwa sebagian besar anak yang belum mengalami menarche cendrung mempunyai persepsi yang negatif terhadap mensruasi, seperti mersa menstruasi itu kotor, jijik, membuat tidak nyamn, dan malu, sehingga mereka merasa belum siap karena takut dan cemas, namun lebih banyak anak yang siap menghadapi menarche. Sebagain besar anak yang sudah pernah diberikan informasi, memiliki pengetahuan yang baik terkait menstruasi, dan anak yang belum pernah mendapat informasi sebagain besar takut dan kaget saat mengalami menarche. Sebagian besar anak yang belum mengalami menarche cendrung kurang siap menghadapi menstruasi dan cendruang mempunyai persepsi yang negatif terhadap mensruasi.
\end{abstract}

Kata kunci: Pengalaman, Kesiapan, Perepsi, menarche

\begin{abstract}
Results of previous studies describe the age of menarche that is getting early. Children who experience early menarche tend to be unprepared and anxious in facing menstrual periods. The purpose of this study is to describe the experiences, perceptions, and readiness of children in facing early menarche.Method: Method of the research used is a qualitative method with in-depth interviews conducted on 20 children aged 10-12 years which later is analyzed thematically. Most children have sufficient knowledge regarding menstruation, however there are some children who have insufficient knowledge because they have never received correct information regarding menstruation, especially from parents. For children who have enough knowledge and information regarding menstruation, they tend to share positive experiences regarding menarche and menstruation. However, in terms of their daily experience among their friend's, they tend to feel that menstruation is something that makes them shy especially those who menstruate earlier than their friends. And from the results of interviews, it was found that most children who have not experienced menarche tend to have negative perceptions of menstruation, such as feeling that menstruation is dirty, disgusting, uncomfortable, and embarrassing, so they feel unprepared for fear and anxiety, but more children are ready to face menarche. Most children who have been given information regarding menstruation, have good knowledge regarding menstruation, and most of children who have never been informed most regarding the same are afraid and shocked when experiencing menarche. Most children who have not experienced menarche tend to be less ready to face menstruation and tendencies have a negative perception of menstruation.
\end{abstract}

Keywords: Experience, Readiness, Perception, Menarche

\section{PENDAHULUAN}

Masa remaja merupakan masa yang mengalami perkembangan fisik paling pesat diantara tahap-tahap perkembangan manusia.
Selain terjadi perubahan fisik, remaja juga mengalami perubahan secara psikologi. Saat ini usia anak mengalami menarche cendrung semakin muda berkisar antara 8-12 tahun. Banyak anak 
yang terlalu dii mengalami menarche mempunyai masalah pemahaman yang kurang dan persepsi yang kurang baik terkait menstruasi. Hal ini disebabkan karena masih jarang anak anak yg mejelang mengalami menarche mendapat informasi karena masih dirasa tabu untuk mengetahuinya terlalu dini (Proverawati, 2009)

\section{METODE}

Studi ini menggunakan rancangan Penelitian kualitatif dengan pendekatan fenomenologi. Pengumpulan data dilakukan dengan melakukan wawancara mendalam pada 20 informan yang berusia 10-12 tahun baik yang belum menarche maupun yang sudah menarche. Pada penelitian ini menggunakan analisa thematic. uraian analisis terperinci mengenai perasaan, pendapat dan persepsi partisipan yang terdapat dalam tema. Dalam interpretasi data nanti akan dihubungkan dengan hasil penelitian terdahulu, dan teori-teori yang mendukung.

\section{HASIL}

\section{Pengetahuan dan Sumber Informasi}

Sebagian besar anak memiliki pengetahuan yang cukup terkait menstruasi terutama yang sudah mengalami menstruasi. Selain pengetahuan tentang menstruasi adalah pengeluaran darah, mereka juga tahu bahwa menstruasi adalah salah satu tanda sudah memasuki remaja dan siap untuk bereproduksi, seperti kutipan hasil wawancara berikut:

\section{"Menstruasi adalah keluarnya darah dari vagina atau area kewanitaan"}

(CN, belum menarche, usia $10 \mathrm{Th}$ )

"Karena menstruasi itu katanya udah kesiapan perempuan untuk bereproduksi”

(AD, sudah menarche, usia $12 \mathrm{Th}$ )

Selain itu, ada juga beberapa anak yang memiliki pengetahuan kurang terkait menstruasi, seperti kutipan hasil wawancara berikut:

\section{"Menstruasi itu katanyakeluarnya darah kotor dari vagina yang terjadi setiap bulan, yang terjadi setiap 28 hri sekali"}

(AD, sudah menarche, usia $12 \mathrm{Th}$ ) "Menstruasi adalah keluarnya darah kotor dari area vagina atau daerah kewanitaan"

(CN, belum menarche, usia $10 \mathrm{Th}$ )

Pengetahuan anak tentang menstruasi dipengauhi oleh sumber informasi dan informasi yang yang didapat oleh mereka. Sebuah penelitian menemukan bahwa ada hubungan antara pengetahun tentang menstruasi dengan kesiapan anak Sekolah dasar dalam menghadapi menarche dan menstruasi (Hastuti et al. 2014). Penelitian lain juga menunjukakan bahwa beberapa responden yang pengetahuannya kurang tetapi siap dalam menghadapi menarche, hal ini bisa disebabkan karena berbagai faktor lainnya seperti adanya dukungan keluarga, pengaruh lingkungan interaksi teman sebaya (Hartatin et al. 2013).

Sebagian besar informan mendapat dukungan yang baik dari keluarganya terutama oleh ibunya. Bentuk dukungan yang didapatkan antara lain adalah diberikannya informasi tentang menstruasi oleh ibunya. Informasi yang didapat dari ibunya antara lain tentang apa itu menstruasi, tanda menstruasi, larangan saat menstruasi, siklus menstruasi dan perawatan selama menstruasi. Informan yang belum mengalami menstruasi masih sedikit yang mendapat informasi dan dukungan dari ibunya. Hanya beberapa informan yang pernah mendapat dukungan dan informasi mengenai menstruasi seperti kutipan berikut:

“..Mungkin beberapa saat lagi kamu sudah mulai remaja, kalau misalnya kalau udah ada bercak-bercak kasi tahu mama biar mama bantuin, nanti harus pakai pembalut"

(AN, belum menarche.Usia $11 \mathrm{Th}$ )

Dari informasi yang didapat dari orang tua tidak semuanya benar saat memberikan tentang informasi mengenai menstruasi. Hal inilah yang bisa membuat informan mempunyai pengetahuan yang keliru tentang menstruasi.Berikut kutipan pernyataan dari informan yang mendapat informasi keliru dari ibunya.

"Kalau menstruasi harus tau cara mengatasi..pakai softek, kalau menstruasi tidak boleh dekat dengan laki-laki..biar ga terlalu banyak keluar darahnya"

(CN, sudah menarche, usia $10 \mathrm{Th})$

Persepsi dan pemahaman remaja tentang menstruasi dipengaruhi oleh peran orang tua yang baik. Peran orang tua yang kurang baik terutama dalam memberikan pemahaman terkait menstruasi, akan berpengaruh terhadap kurangnya pemahaman mereka tentang menstruasi yang bisa mengakibatkan persepsi yang negatif (Hartatin et al. 2013). Selain dari orang tua, informan juga mendapat informasi tentang menstruasi dari temantemannya. Informasi yang didapat antara lain tentang pengalaman teman lain yang sudah mengalami menstruasi, seperti tentang rasa sakit perut ketika menstruasi, temannya diejek oleh teman laki-laki, ketidaknyamaan saat menstruasi dan informasi tentang apa itu menstruasi. Berikut kutipan pernyataan dari informan yang mendapat informasi yang dari temannya.

"Kalau dah menstruasi artinya dah remaja, ga boleh dideketin cowok, nanti bisa hamil gitu katanya"

(DV, sudah menarche, usia $11 \mathrm{Th}$ ) 
"Paling cuman nanya-nanya menstruasi itu sakit nggak, katanya ada yang sakit ada yang enggak"

(MR, belum menarche, usia $12 \mathrm{Th}$ )

Dari kutipan diatas terlihat bahwa informasi yang diterima oleh informan yang belum mengalami menstruasi lebih banyak tentang pengalaman temannya ketika mnstruasi, dan lebih banyak pengalaman yang kurang menyenangkan seperti sakit perut saat menstruasi, perasaan cemas dan takut pada teman laki-laki. Hampir sebagian dari informan pernah mencari informasi terkait menstruasi kepada temannya. Sebuah penelitian mengungkapkan bahwa belum semua remaja mendapatkan informasi yang benar dan lengkap tentang kesehatan reproduksi (Widodo 2009).

\section{PENGALAMAN}

Secara umum, sebagian besar informan pernah mempunyai pengalaman terkait menstruasi, baik pengalaman yang dialami sendiri atau yang dialami orang lain dan pengalaman yang menyenangkan maupun kurang menyenangkan.ada beberapa informan tidak tahu ketika menstruasi pertama itu adalah menstruasi. Berikut kutipan penyataaan dari informan tentang pengalamannya saat menstruasi pertama.

"Pertama tu panik. Pas Adel kencing, kok ada darah, adel tanya sama mama owh kamu sudah haid, ga papa kata mama, ga usah panik, trus mama ngajarin cara-caranya..karena kan pertamanya tu adel kencing koq kayaknya tu keluar darah kayak cairan darah, adel teriak, trus kata mama ga papa itu menstruasi berarti kaтu tu udah menjelang ke remaja..Paniknya karena keluar darah"

(A.I, sudah menarche, usia $12 \mathrm{Th}$ )

Banyak anak perempuan yang merasa takut karena melihat banyak darah yang keluar, sakit perut dan terkadang muntah-muntah (Elizabeth B. Hurlock 2002). Informan pernah mempunyai pengalaman yang dianggap tidak menyenangkan oleh mereka yang didapatkan oleh orang lain sehingga membuat mereka merasa takut dan cemas ketika akan mengalami menstruasi. Pengalaman tersebut seperti melihat atau mendengar temannya mengalami nyeri saat menstruasi. Berikut kutipan penyataaan dari informan:

"Takut sakit perut kayak temenya ...takut sama darah juga"

(DI, belum menarche, usia $10 \mathrm{Th}$ )
"Takut diejek-ejek sama temen yang cowo, takut cepet gede, ya takut gitu . ga tau takut aja"

(DI, belum menarche, usia 10 tahun) "Takut ketahuan cowok, nanti diketawain sama temen cowok"

(KR, sudah menarche, usia $12 \mathrm{Th}$ )

Responden pernah mempunyai pengalaman yang dianggap tidak menyenangkan oleh mereka yang didapatkan oleh orang lain, sehingga membuat mereka merasa takut dan cemas ketika akan mengalami menstruasi. Pengalaman tersebut seperti melihat atau mendengar temannya mengalami nyeri saat menstruasi. Berikut kutipan penyataaan dari responden:

"Waktu dulu biasanya mendengar menstruasi itu sakit gitu, dulu tu sempet takut sakit...Kan sering sakit perut temennya, akhirnya ditanya koq kamu sering sakit perut, di ceritain ternyata sudah M...Kalau misalnya mereka sakit perut, ya kebayang sich ntar kalau dila menstruasi kira kira sakit perut ga sich, cemas gitu"

(AL, sudah menarche, usia $11 \mathrm{Th}$ )

"Takut diejek kayak temennya. Takut sakit perut kayak temenya, takut sama darah juga. Khawatir cepet remaja, ga tau takut aja"

(DI, belum menarche, usia 10 tahun)

Dari hasil wawancara ternyata ada informan yang tidak merasa cemas, takut atau pun kaget seperti teman lainnya ketika menarche. Hal ini dikarenakan mereka sudah mendapat penjelasan dan informasi tentang menstruasi dari orang tua sebelum mereka mengalami menstrasi pertama.

Berikut kutipan pernyataan dari informan:

"Biasa aja sich... Seneng"

(KR, sudah menarche, usia $12 \mathrm{Th}$ )

"Pengen kencing, terus ngeliat ada darah, kasi tau mama, bilang sudah men. Disuru pake pembalut, abis tu inget ganti pembalut sama celana dalam, sering ke kamar mandi, disuru mandi juga seringin. Udah itu aja.Sebenernya udah tau sih kalo itu menstruasi, soalnya adiknya duluan, adiknya udah

menstruasi, sebulan kemudian baru saya. Jadi agak udah biasa aja"

(BR, sudah menarche, usia $12 \mathrm{Th}$ )

\section{SIKAP DAN PERSEPSI}

Secara umum, sebagian anak mempuyai sikap dan persepsi yang kurang baik terhadap menstruasi, ada yang merasa takut, gelisah, cemas, 
takut ketahuan temannya, dan takut tembus. Hal ini dikarenakan pengalaman yang dialami oleh mereka yang dapat mempengaruhi sikap dan persepsi mereka terhadap menstruasi.

Berikut kutipan pernyataan dari informan:

"Risih ga nyaman...Jijik sama geli...Kan dicelananya ada merah merah gitu, aneh aja rasanya"

(NI, sudah menarche, usia $12 \mathrm{Th}$ )

"Setiap kemana mana gelisah takut bocor bawa softek kemana mana.Takut sakit perut.

(VR, sudah menarche, usia $11 \mathrm{Th}$ )

"Takut diejek kayak temennya. Takut sakit perut kayak temenya, takut sama darah juga. Khawatir cepet remaja"

(DI, belum menarche, usia $10 \mathrm{Th}$ )

Pengetahuan, dukungan keluarga, dan sumber informasi yang salah akan menimbulkan sikap negatif seorang anak remaja dalam menghadapi menarche dan menstruasi. Sebuah penelitian yang dilakukan pada remaja putri Sekolah Menengah Pertama didapatkan hasil bahwa terdapat $45,2 \%$ remaja putri mempunyai sikap yang negatif terhadap menarche dan hasil uji statistik menyebutkan bahwa ada hubungan yang signifikan antara sikap dengan kesiapan remaja putri dalam menghadapi menache (Hartatin et al. 2013).

\section{KESIAPAN MENGHADAPI MENSTRUASI}

Secara umum dari hasil wawancara mendalam, masih banyak informan yang belum siap dalam menghadapi menstruasi terutama yang belum mengalami menstruasi. Informan yang mengatakan sudah siap untuk menghadapi menstruasi, dikarenakan mereka sudah dibekali informasi yang cukup mengenai menstruasi. Mereka merasa bahwa perempuan pasti mengalaminya sebagai tanda sudah memasuki masa remaja. Berikut kutipan pernyataan dari informan.

"Siap, kan semua pasti mengalami... "Tak tanya mama, koq menstruasi, Iya semua cewek harus menstruasi, kalau enggak, kenapa, nanti ga bisa punya anak, kaya gitu dibilang. Kalau sudah mentruasi katanya sehat"

(IN, sudah menarche, usia $12 \mathrm{Th}$ )

Dari hasil wawancara didapatkan juga bahwa mereka sebagian mempunyai perasaan gelisah, perasaan cemas, takut, kurang nyaman, dan malu mengungkapkan menstruasinya. Berikut kutipan pernyataan dari informan.

"Malu, karena takut ditauin menstruasi"

(DV, sudah menarche, usia $11 \mathrm{Th}$ )

"Masih takut, katanya baru pertama sakit banget perutnya"

(DW, belum menarche, usia $11 \mathrm{Th}$ )

"Belum siap, masih takut...Takut sakit perut kayak temennya"

(DI, belum menarche, usia $10 \mathrm{Th}$ )

Responden yang mengatakan sudah siap untuk menghadapi menstruasi, dikarenakan mereka sudah dibekali informasi dan pengalaman mengenai menstruasi. Mereka merasa bahwa perempuan pasti mengalami menstruasi sebagai tanda sudah memasuki masa remaja. Berikut kutipan pernyataan dari responden:

"Udah siap, karena dah tahu semuanya, dah dikasi tahu...Ya kalau sudah menstruasi berarti sudah remaja"

(NI, sudah menarche, usia $12 \mathrm{Th}$ ) "Sudah aja setelah beberapa kali...ya dikasi motivasi sama ibunya...kalau sudah menstruasi berarti sudah remaja"

(NI, sudah menarche, usia $12 \mathrm{Th}$ )

Kesiapan anak dalam menghadapi menstruasi tidak hanya memerlukan kesiapan fisik namun juga memerlukan kesiapan secara psikologis. Dukungan social dari keluarga dan lingkungan sangat penting untuk menduung kesiapan anak dalam menghadapi menstruasi (Erviana, 2012).

\section{SIMPULAN}

Sebagain besar anak yang sudah pernah diberikan informasi, memiliki pengetahuan yang baik terkait menstruasi, dan anak yang belum pernah mendapat informasi sebagain besar takut dan kaget saat mengalami menarche. Sebagian besar anak yang belum mengalami menarche cendrung kurang siap menghadapi menstruasi dan cendruang mempunyai persepsi yang negative terhadap mensruasi.

\section{DAFTAR PUSTAKA}

Aflaq, F. \& Jami, H., 2012. Experiences And Attitudes Related To Menstruation Among Female Students. Pakistan Jurnal Of Psycological Recearch, 27(2), Pp.201-224.

Elizabeth B. Hurlock, 2002. Psikologi Perkembangan, Jakarta: Erlangga.

Erviana Ulfa, 2012. Hubungan Dukungan Keluarga Dengan Tingkat Kecemasan Pada Remaja Putri Dalam Menghadapi Menarche Di Mi Salafiyah Simbang Kulon 02 Kabupaten Pekalongan. , Xxxiii(2), Pp.81-87. Available 
At:

Http://Www.Ncbi.Nlm.Nih.Gov/Pubmed/150 03161.

Hartatin, Y., Hariani, H. \& Makassar, N.H., 2013. Faktor-Faktor Yang Berhubungan Dengan Kesipan Remaja Putri Dalam Menghadapi Menarche Di Smp Negeri 4 Pare] 2, Pp.1-7.

Proverawati, M., 2009. Menarche $N_{4}$ si
Pertama Penuh Makna, Yogyakarta: Nuha Medika.

Tulus Puji Hastuti , Sri Wis ৈssih, A.A., 2014. Hubungan Tingkat tahuan Tentang Menstruasi Dengan an Menghadapi Menarche Pada Siswi Kelas V Dan Vi Di Sd Negeri Dangkel Parakan Temanggung Tahun 2014. Jurnal Kebidanan, 3(7), pp.16-23. 
Diaris.N.M.,Pramita.I / Kesehatan Terpadu 3(1) (2019) 